\title{
Theoretical and methodological discussion on social and cultural memory in international perspective
}

\author{
dr hab. Grzegorz NYCZ
}

\begin{abstract}
The following text is centered on theory and methodology of memory studies in international perspective. The text explains the differences between focus and scope of various approaches to memory studies, those relying mostly on collective experience, those discovering cultural memory and the approach centered on the social dimension of the latter. The aim of the paper is to give a short introduction to key research accomplishments in the area of memory studies and to present short account on the critically disputed important international cases of high importance of memory in world politics. The paper presents various methodological paths to study memory as a part of social, cultural and collective experience, focusing on current international discussions regarding how past may impact present global relations. The presented methodological orientations are both contributing to better understanding of the construction of the past in public/ social area and to the knowledge on conscious efforts of controlling the selected chapters of history to serve the national (or ideological) purpose.
\end{abstract}

\section{Keywords}

memory studies, collective memory, social memory, cultural memory

\section{Introduction}

Modern memory studies rely on theoretical concepts linking sociology and history through collective, social and cultural dimensions of preserving remembrance as a public task. Key concepts described and analyzed in the following text encompass social, collective, cultural understandings of reviving the past in present-day public concern. The text is centered on those applications of memory studies methodology that contribute to largest extent to the closer look on international controversies regarding history, and most divisive aspects of modern historical disputes. The exemplifications of dilemmas explained by memory studies methodologies include Holocaust recollections, Israeli national reconstruction, postcommunist historical rows, 21 th century terrorism. The text is focusing on methodological traits (memory as collective, social or cultural concept) to distinguish between various leading schools and scholarly approaches to memory studies in the context of the evolution 
of international environment and pressure coming from latest political challenges. Memory studies seem not to be immune to public or government-oriented mobilization seeking answers to most up-to-date controversies of broader concern. Interestingly, the vast load of methodological input could locate memory studies among most potent and influential research backyards serving policy makers with in-depth social science or humanitiesrooted expertise or recommendations. Whether such a remedy would serve rather present political goals, or the sake of science and research itself, remain a disputable issue. ${ }^{1}$

\section{Collective memory}

Jeffrey Olick developed a concept of politics of regret, relying on earlier Halbwachs' studies of collective memory, seeing the post-Cold War memory politics as drifting towards practical resolution of annoying past national failures ("toxic legacies"), using two analytical frameworks (philosophical jurisprudence and transitology). ${ }^{2}$ In 1938 Maurice Halbwachs defined "collective psychology" as a process of consideration of psychological facts brought about from the group-level of human activity, from the state of being associated in a group. ${ }^{3}$ Nicholas Russell claimed that "collective memory" as term existed for centuries before Halbwachs coined it in 1925 under French label "mémoire collective", reaching as far as Ancient Greece and its views on remembering in the linkage with immortality, and focusing on French texts since 16th to 18th century (involving a concept of collective memory), including Montaigne, Ronsard, Rousseau, and even Cid (Pierre Corneille). ${ }^{4}$ Erika Apfelbaum concluded that Halbwachs' concept of collective memory was necessarily social, with its inherent view of socially organized human activity in general and a social (dynamic) process of selection of individual remembrance to distinguish recollections ("les souvenirs") as consciously constructed reminiscences of the past. ${ }^{5}$ T. Hirsch presented Halbwachs as a representative of Durkheimian sociological school with an eye on collective psychology (based on empiricism and phenomenological sociology). ${ }^{6}$ The development of Halbwachs and Durkheim notion on collective memory and the role of religion came

1 Conf. TROEBST, Stefan: Surfacing of the "Titanic" in the Balkan Bermuda Triangle: Historical-political Conflicts between Sofia, Skopje and Athens before and after 1989, in: History as an Instrument of Contemporary International Conflicts, International Conference, Cracow, October 25-27, 2018, eds. RYDEL, Jan - TROEBST Stefan.

2 OLICK, Jeffrey: The Politics of Regret. On Collective Memory and Historical Responsibility, Routledge, New York 2007, 122.

3 HALBWACHS, Maurice: Individual and Collective Psychology, in: American Sociological Review, 3, 1938, 5, 615.

Halbwachs was seeking for collective memory in the understanding of the past as thoughts of groups that no longer exist, that belong to history. HALBWACHS, Maurice: La mémoire collective et le temps, Cahiers internationaux de sociologie, 101, 1996 (1947), 45.

4 The supporter of Halbwachs' definition of collective memory, Pierre Nora, as Russell explained brought a focus on group identity and distinction between collective and historical form of memory. RUSSELL, Nicolas: Collective Memory before and after Halbwachs, in: The French Review, 79, 2006, 4, 792-799.

5 APFELBAUM, Erika: Halbwachs and the Social Properties of Memory, in: Memory: Histories, Theories, Debates, ed. RADSTONE, Susannah - SCHWARZ, Bill, Fordham University Press, New York 2010, 85.

6 HIRSCH, Thomas: A Posthumous Life. Maurice Halbwachs and French Sociology (1945-2015), translated by Peter Hamilton, in: Revue française de sociologie, 57, 2016, 1, 63. 
with Daniele Hervieu-Leger research, with a further focus on religion seen, as D. MacNeill underlined, as a way to mobilize collective memory through rituals, symbols and myths related to the origins of a particular community. ${ }^{7}$ Emile Durkheim gave an example of the linkage between religion and (public, collective) memory examining the rituals of mourning, reaching beyond ceremonial regret and revocation of the dead member of the community's contributions, towards much deeper self-identification with the deceased within the public presentation of sorrow, including self-torture or even self-burning. ${ }^{8}$ Surprisingly, the Indian traditional Sati ceremony of burning the wife of the deceased on his funeral pyre survived until the 21 th century (such Hinduist practice, law-forbidden, were still present, but rare). ${ }^{9}$ Danièle Hervieu-Léger explained the chain of memory in the context of religious rites that necessarily implied the "lineage" of belief i.e. a conscious effort to build collective memory on the religious past, which may refer to a myth of creation in most traditional societies, and through anamnesis understood as recalling the past performed as a ritual, so those repeated efforts understanding religion as repeating the rites, supported by collective memory mobilized, serve continuity in belief, practice and religious memory upkeep (taking religious for collective as well), while this chain (lineage based) of memoires is dependent on ritualized revocations of one's community foundation ("foundational events"). ${ }^{10}$ So, to memory studies area belongs also religious activity of society.

Next to Halbwachs' and Nora distinctions between history and memory Joseph Llobera mentioned Bernard Lewis and his 1975 distinction regarding remembered history, recovered history and invented history (the latter fabricated). ${ }^{11}$ Lewis began his lecture on historical policy of the modern Middle East with such examples as Masada celebration 2500 anniversary of the founding of Iran by Cyrus, Egyptian celebrations of 969 foundation of Cairo by caliph al-Mu'izz, Turkish celebrations of the conquest of Constantinople (500

7 MACNEILL, Dominique: Extending the work of Halbwachs: Danièle Hervieu-Léger's analysis of contemporary religion, Durkheimian Studies, 4, 1998, 78.

Conf. HERVIEU-LÉGER, Danièle: Space and Religion: New Approaches to Religious Spatiality in Modernity, International Journal of Urban and Regional Research, 26, 2002, 1, 99-105.

8 DURKHEIM, Emile: The Elementary Forms of the Religious Life, translated by Joseph Ward Swain, Free Press, New York 1965, 444.

9 in some cases Sati suicide on the pyre (forbidden in British India since 1829) was voluntary, in some forced by other family members. BBC News, India wife dies on husband's pyre, August 22, 2006, news.bbc.co.uk/2/hi/ south_asia/5273336.stm, Conf. HARDING, Luke: The ultimate sacrifice, The Guardian, August 23, 2002, https:// www.theguardian.com/world/2002/aug/23/gender.uk1.

PESTA, Jesse - RANA, Preetika: In Indian Families, the Dangerous Meeting of Women and Fire, The Wall Street Journal, July 22, 2015, https://www.wsj.com/articles/in-indian-families-the-dangerous-meeting-of-women-andfire-1437606446.

Conf. Dorothy K. STEIN, Women to Burn: Suttee as a Normative Institution, Signs, 4, 1978, 2, $253-268$.

SINGH, Bhajan: Institution of Sati in Medieval India with Special Reference to Pre-Colonial Punjab, Proceedings of the Indian History Congress, 71, 2010-2011, 256-265.

DHILLON, Maninder: Widow Burning: The Burning Issue of Colonial Britain and India, Blog, Utrecht University, 2019, https://cchr.uu.nl/widow-burning-the-burning-issue-of-colonial-britain-and-india/.

10 HERVIEU-LÉGER, Danièle: Religion as a Chain of Memory, translated by Simon Lee, Rutgers University Press, New Brunswick 2000, 124-125. Lineage in the understanding of ancestry, shared one progenitor i.e. past ancestor - Merriam Webster, https://www.merriam-webster.com/dictionary/lineage.

11 LLOBERA, Joseph: Halbwachs, Nora and "history" versus "collective memory": a research note, Durkheimian Studies, 1, 1995, 40. Conf. LEWIS, Bernard: History. Remembered, Recovered, Invented, Princeton University Press, Princeton 1975. 
anniversary) or victory at Manzikert $1071 .{ }^{12}$ In the context of the celebrations of Masada and Iranian (Persian) beginnings Lewis described three types of historical narrative, based on the traditional personal formula who-when-where, more advanced approach focused on the topic, i.e. what-how, or even why, and finally due to methodology of sources and its exploitation, as well as ideology of historians, their chosen functions and goals of study. ${ }^{13}$ Bernard Lewis' typology encompassed:

- a remembered history, i.e. mostly statements concerning the past, including personal recollections, scriptures, historiography understandable as a collective memory (community's, nation's), a result of a conscious decision, what exactly the leaders or intellectuals chose to remember,

- a recovered history, consisting of discoveries of forgotten chapters of the past (events, movements, man and ideas) due to a conscious decision of a community (to reject it) and restored by an academic effort (of such sophistication as deciphering lost writings or languages), leading to a reconstruction of the past bearing a threat of becoming rather a creative work on reinventing the past,

- invented history, a premeditated effort to build a certain vision of the past coming from an earlier purpose, using both recovered history and fabrication. ${ }^{14}$

Reinhart Koselleck distinguished between two aspects of methodological approach towards history:

- oriented towards events and actions,

- diachronic (following de Saussure), regarding the transformation of social structures (over time), as well as its presence in languages. ${ }^{15}$

Corning and Schuman explained that collective memory was describing how groups bring back the past in their memoirs or start analyzing it ("recall and think about the past"), in other words, the term refers to a shared set of reminiscences, which belong to a particular group. $^{16}$

Paul Ricoeur set a stage for his analysis of collective memory by a review of predominant figures of French historiography of the first 2/3 of the 20th century, i.e. Fernand Braudel (with his opus magnum of 1979 "Civilization and Capitalism, 15th-18th century", not following Weber's protestant ethics and capitalism thesis) and the school of periodical Annales, followed by intellectual ferment of the period of a crisis, analyzing methodological crisis through the lens of history of mentalities (also in crisis) borrowed from sociology of Lucien Lévy-Bruhl, while the latter double crisis could be brought into order by rigors of mentality owing to Michel Foucault, Michel de Certeau and Norbert Elias. ${ }^{17}$

12 LEWIS, Bernard: History. Remembered, Recovered, Invented, 3-4.

13 Ibidem.

14 Ibidem.

15 KOSELLECK, Reinhart: Social History and Conceptual History, in: International Journal of Politics, Culture, and Society, 2, 1989, 3, 318.

16 ("memory shared by the members of a group") CORNIG, Amy - SCHUMAN, Howard: Generations and Collective Memory, The University of Chicago Press, Chicago 2015, Kindle, Loc. 61, Loc. 109

17 RICOEUR, Paul: Memory, History, Forgetting, translated by Kathleen Blamey and David Pellauer, The University of Chicago Press, Chicago \& London 2006, Kindle, Loc. 2784, Loc. 2879-2888.

Conf. WEBER, Max: The Protestant Ethics and the Spirit of Capitalism, translated by Talcott Parsons, Charles Scribner's Sons, New York 1958. 
Pierre Nora explaining concepts of sites or parts of memory (lieux de memoire) and centers of memory (milieu), claimed that all aspects of recollecting notable past events publicly must be directed consciously in the modern post-war age, because spontaneous attempts of public memory celebration would no longer occur due to the strong pressure of ongoing historical processes that make conservation of those critically important memory sites impossible. ${ }^{18}$ Kelland noted that the collective memory (understood as being partly a product of mass culture, which served also as a media of the shares memoirs) allowed her to develop on her concept of memory practices, i.e. efforts of history activists (community historians) to revoke some marginalized parts of common history through innovative strategies of research, archival work (rediscovered by opening nontraditional sources) and communication reaching inside the researched group (relying on its social activists), particularly useful in studies of minorities leading to the challenge to mainstream history (dominant narratives). ${ }^{19}$

Gedi and Elam critique of Halbwachs collective memory concept as leading to a controversial thesis on illegitimacy of individual memory (not truly existing, being a derivative of social memory) concluded that the overreliance on the first to the expense of the latter undermined methodology of history as a science, giving priority to social judgments on the past and marginalizing historical facts as a field of research conducted by historians. ${ }^{20}$

Halbwachs' stance could be linked to sociological realism, stressing that political attitudes were not coming from individual temperaments but derived from collective determinants of permanent appearance, noting that groups affected individuals in uneven scale, depending on one's personal characteristics. ${ }^{21}$ Sociological realism is mentioned here in the understanding that groups exist materially (as opposite to sociological normativism stating that social groups are just a sum of entities, their members). Causal realism (following T. Brante) referring to Durkheim postulated that social reality is material, real. ${ }^{22}$ On the ground of legal studies Hubert Rottleuthner explained that normativism sees law as binding due to its inherent force and the norms themselves as independent from their application or evaluation, while realism tends to reduce norms to (social) facts, i.e. events or circumstances existing objectively, bound by time and space, seeing norms as nonexistant, without any context, that may empirically verified. ${ }^{23}$

18 NORA, Pierre: Between Memory and History: Les Lieux de Mémoire, translated by Marc Roudebush, in: Representations, 26, 1989, 12.

19 seeing social movement activists as also pre-historians ("proto-public historians") who challenged the power of archives as tool of leadership through alternative interpretation of sources from the archives ("reading archival traces against the grain"). KELLAND, Lara Leigh: Clio's Foot Soldiers. Twentieth-Century U.S. Social Movements and Collective Memory, University of Massachusetts Press, Amherst and Boston 2018, Kindle edition, Loc. 192, 245-258.

20 GEDI Noa - ELAM, Yigal: Collective Memory - What Is It?, in: History and Memory, 8, 1996, 1, 37-40.

21 HALBWACHS, Maurice: The Psychology of Social Class, translated by Claire Delavaney, William Heinemann, London 1958, 4, 7.

22 BRANTE, Thomas: Consequences of Realism for Sociological Theory Building, in: Journal for the Theory of Social Behaviour, 31, 2001, 2, 172.

Conf. WAHLBERG, Tobias Hansson: Elder-Vass on the Causal Power of Social Structures, in: Philosophy of the Social Sciences, Sage, Online August 29, 2013, https://lucris.lub.lu.se/ws/files/1304165/4612198.pdf, doi:10.1177/0048393113500213. On material dimension of social facts (following Durkheim) - SAARISTO, Antti Jussi: Social Ontology and Agency. Methodological Holism Naturalised, Presented to the University of London for the degree of Doctor of Philosophy, March 2007, 26, http://etheses.Ise.ac.uk/2561/1/U615510.pdf.

23 Hubert Rottleuthner, Foundations of Law, in: A Treatise of Legal Philosophy and General Jurisprudence, Vol. 2, eds. PATTARO, Enrico, Springer, Dordrecht 2005, 7. 
Apart from anniversary celebrations, popular examples of shaping collective memory refer to national exhibitions, like the well preserved museums of Holocaust sites in Central and Eastern Europe, focused on Nazi Germany's WWII concentration camps. Apart from best known Auschwitz, a well preserved site was funded in Czech to present Terezín (18th century Austro-Hungarian building honouring empress Marie Therese near Prague) used by Nazi Germany as concentration camp and Jewish ghetto, from where transports to Auschwitz were send as a part of planned extermination. ${ }^{24}$

\section{Cultural memory}

Jan Assmann defined cultural memory as an external dimension of human memorizing sphere connected with such non-internal factors of remembrance as conditions imposed by society on an individual and cultural context of his life. ${ }^{25}$ In this frame, cultural memory (reported by J. Assmann as a follow-on of Halbwachs study) constitute one of four external areas of human memory, next to " "mimetic memory»" based on imitation leading to manners and customs, "«the memory of things»" (objects giving an image of practical life and taste of the past), " "communicative memory»" (based on language and communication skills). ${ }^{26}$ In J. Assmann definition cultural memory should be understood as inherited or learned ability to catch a glimpse of certain meaningful rituals (beyond practical forms of behavior), such that could be included in the present-day forms of life (embracing old symbols, icons or even idols reintroducing past representations of identity). ${ }^{27}$

Erll defined cultural memory as one of dimensions of memory which is strictly connected with attempts to objectivize material observations through a conscious and ceremonial process, with a ready-made list of contents and meaning, used to strengthen memorizing events ("mnemonic canon"), using such "media" transmitters as shamans, priests or (sic!) archivists. ${ }^{28}$ In Erlls definition cultural memory is centered on mythical history with a special community-building significance (seeing as mythical the defense of Troy and Jewish escape from Egypt, to be finally confirmed by archeological evidence but treated as unconfirmed due to lack of hieroglyphic images of Jews). ${ }^{29}$ Another Erll definition of cultural memory stated that it described biological or social processes linking past and the contemporary set in social and cultural frameworks. ${ }^{30}$

24 MUNK, Jan: Activities of Terezín Memorial, in: The Public Historian, 30, 2008, 1, 73-79. Terezín Children of the Holocaust, http://www.terezin.org/the-history-of-terezin. Terezín Memorial National Cultural Monument, https://www.pamatnik-terezin.cz/small-fortress.

25 ASSMANN, Jan: Cultural Memory. Writing, Remembrance, and Political Imagination in Early Civilization, translated by Henry David Wilson, Cambridge University Press, Cambridge 2011, 4-6.

26 Ibidem.

27 the latter functions of old symbolic forms (transcending memory of objects and not merely practical but showing aspects of identity was linked by J. Assmann with " "social memory»" of Aby Warburg. ASSMANN, Jan: Cultural Memory. Writing, Remembrance, and Political Imagination in Early Civilization, 4-6.

28 ERLL, Astrid: Regional integration and (trans)cultural memory, in: Asia Europe Journal, 2010, 8, p. 311.

29 Ibidem.

30 ERLL, Astrid, Cultural Memory, in: English and American Studies, eds. MIDDEKE, Martin et altera, J. B. Metzler, Stuttgart 2012, 238. 
Cristian Tileagă relied on J. Assmann definition of cultural memory to explain that in the case of former Soviet bloc a conflict between collective memory in post-communist countries and cultural memory regarding communism was resolved to the benefit of cultural memory of communism responsible for post-communist nostalgia. ${ }^{31}$

Lensen (2017) stressed that the shifts in cultural memory definitions lead to a starker emphasis on its semantic backing ("connectivity"), open-ended follow-ups and abandonment of strict territorial restrictions. ${ }^{32} \mathrm{~S}$. Vervaet in the Bosnian context claimed that literature lost its primary role as a medium of collective and cultural memory. ${ }^{33}$

Nalborczyk (following Erll) found two dimensions (levels) of cultural memory (seeing it in collective memory context):

- individual (cognitive),

- social (group's efforts to construct common past through institutions and media), while on both of those levels appear interactions that confirm the casual relation between the cultural memory and collective content coming from individual's contacts with other people. ${ }^{34}$

Issler explained that Halbwachs collective memory was antithetical to Freudian view on memory as individually constructed set of recollections, in its attempt to show memory as a social construct, which laid foundation to late 20th century cultural studies concept of memory (reversing the view on culture as a phenomenon of memory, history, to see memory as a phenomenon of culture). ${ }^{35}$ Issler relied on Jan Assmann typology, deriving cultural memory from the broader Halbwachsian framework through a division of collective memory into two separate memory branches, i.e. communicative and cultural. ${ }^{36} \mathrm{~J}$. Assmann defined communicative memory as events of a recent past, shared by groups or generations and forgotten as years of their active life come to pass (while those groups are seen in this contexts as vehicles, "carriers", of communicative memory, and when the generation members die, a new memory replaces the one carried by them, lasting for a "biblical" period of three to four generations in terms of a time limit of a certain debt of the generations responsible). ${ }^{37}$ Importantly, Jan Assmann explained legal Roman practice on the matter of such generation based recollections in the logic of saeculum,

31 TILEAGĂ, Representing Communism After the Fall. Discourse, Memory, and Historical Redress, Palgrave Macmillan, Cham 2018, 60.

32 J. Lensen, Towards a Transnational Ethics for Europe: Memory and Vulnerability as Gateways to Europe's Future in Koen Peeters's Grote Europese roman, in: The Changing Place of Europe in Global Memory Cultures. Usable Pasts and Futures, eds. KRAENZLE, Christina - MAYR, Maria, Palgrave Macmillan, Cham 2017, 88.

33 Bosnian prose related to war makes cultural memory less heroic, as S. Vervaet analysed. VERVAET, Stijn: Writing war, writing memory. The representation of the recent past and the construction of cultural memory in contemporary Bosnian prose, in: Neohelicon, 38, 2011, 15.

34 NALBORCZYK, Agata: Community Life: Cultural Memory and the Construction of a Contemporary Muslim Tatar Identity in Poland, in: Contested Memories and the Demands of the Past. History Cultures in the Modern Muslim World, ed. RAUDVERE, Catharina, Palgrave Macmillan, Cham 2017, 151.

35 IBLER, Roland: Cultural memory, in: The Bonn Handbook of Globality, eds. KÜHNHARDT, Ludger - MAYER, Tilman, Vol. 2, Springer, Cham 2019, 807.

36 IBLER, 809. ASSMANN, Cultural memory, 33.

37 ASSMANN, Cultural memory, 35-36. Notably, in the latter case (Holocaust memory in Germany) J. Assmann found a critical point of saeculum in von Weizsacker speech on May 8, 1945 in the Bundestag and the outbreak of Historikerstreit coming from that call. ASSMANN, Cultural memory, 35-36. 
lasting until the latest survivors of the passing generation died (here the example of last Romans remembering the Republic, dead by the year 22 due to Tacitus account was used, and the gradual passing of a generation or its members that held personal memory or experience of recent past was linked with a threshold of 40 years, half of the limit for those three-four generations, as breaking point after which those who remembered personally, like witnesses of German Nazi crimes against Jews, would retire, so that memory kept alive by witnesses become replaced by media-driven memory). ${ }^{38}$

J. Assmann's cultural memory was built by unordinary efforts of professionals, from shamans and priests to teachers, scholars or artists, that made an unexpected presentation of some particular events from the past, acting as special carriers of memory, that had nothing to do with everyday life of a society. ${ }^{39}$

\section{Memory boom}

Langenbacher linked the predominance of history boom and collective memory concept in 21th century international relations with constructivist school's outreach in terms of questioning realist claims on centrality of power-maximizing state behavior or inadequacies of liberal views on international norms, following John Hobson and Alexander Wendt, next to the impact of memorable international traumatic events such as 9/11 or dark legacies of repressive regimes (since the Holocaust), combined with the growing scale of international legal institutions revoking aspects of public memory to sustain it in such critical topics as genocide (Nazi era and after) and the influence of diasporas (like Armenian memory of Turkish-led genocide). ${ }^{40}$

Cubitt connected "memory turn" of the late 20th century historical studies with

- the rise of social historians interest in empirically accessible social processes (related to human experience),

- introduction of new methodology of mental and social factors of remembering by the new oral history school,

- growing concern of historians of culture and social processes in exploring interlinkages between oral and literature-based history,

- engagement of cultural and intellectual history in discovering the significance of past events in the formation of political and religious ideologies,

- mental dimension of reality and subjectivity analyzed by postmodern school,

- historians' effort to analyze traumatic impact of total war and genocide on groups and individuals,

- efforts to reveal truth about history of former East bloc societies hidden by communist regimes. ${ }^{41}$

Correspondingly, Joan Tumblety described "memory boom" (since the late 20th century)

38 ASSMANN, Cultural memory, 35-36.

39 ASSMANN, Cultural memory, 39.

40 LANGENBACHER, Eric: Collective Memory as a Factor in Political Culture and International Relations, in: Power and the Past. Collective Memory and International Relations, eds. LANGENBACHER, Eric - SHAN, Yossi, Georgetown University Press, Washington D.C. 2010, Kindle, Loc. 184, 200, 267-312 (184-711).

41 CUBITT, Geoffrey: History and Memory, Manchester University Press, Manchester 2007, Kindle, Loc. 62-72. 
as a newly discovered run towards historical study reaching across the world of popular culture to the academia, transgressing boundaries of research disciplines, including the humanities (music) and social science, cognitive psychology, neuroscience. ${ }^{42}$

\section{Social memory}

Jan Assmann linked the emergence of social memory with Aby Warburg. ${ }^{43}$ Warburg linked remembrance on individual and collective level with the artist's range of psychological stretch in his approach to work out an artistic style (between the poles of tranquility and passion, or in other terms scientific-mathematical and religion-oriented approach), while memory strengthens such polarization. ${ }^{44}$ Warburg saw the emergence of civilization in a conscious distance built between one's mind and the external world, which reached a certain social role. ${ }^{45}$ Importantly, memory (recollection, both individual and non-individual) in Warburg's view helps the artist, in his fluctuations between religion and mathematics as a basis to find one's grip on the world (the oscillation itself between the two poles, i.e. inward fantasy and outward rationality is presented by this theorist of culture as formative (serving the creation of new artistic acts)..$^{46}$

Connerton persuaded that social memory analysis should concern the significance of images of the past in terms of legitimizing through those patterns a social order of particular in the present time. ${ }^{47}$

In the context of the late 20th century turn towards oral history Nathan Wachtel mentioned among the American pioneers of this field of study Lyman Cooper Draper (and his 1840s

42 TUMBLETY, Joan: Introduction. Working with memory as source and subject, in: Memory and History. Understanding memory as source and subject, ed. TUMBLETY, Joan, Routledge, London 2013, Kindle Loc. 135145.

43 ASSMANN: Cultural memory, Loc. 222.

Conf. WARBURG, Aby: The Absorption of the Expressive Values of the Past, translated by Mathew Rampley, in: Art in Translation, 1, 2009, 2, 273-283.

44 WARBURG: The Absorption of the Expressive Values of the Past, 277.

The Mnemosyne Atlas of Warburg (an exhibition) consisted of large (ca $150 \times 200 \mathrm{~cm}$ ) photographs presented on wooden panels, depicting cosmographic and art-historical collection, maps, manuscripts, as well as pieces from contemporary (1920s) media. JOHNSON, Christopher D., About the Mnemosyne Atlas, The Warburg Institute, Cornell University Library, 2013-2016, https://warburg.library.cornell.edu/about

Cornell University Library, Mnemosyne. Meanderings through Aby Warburg's Atlas, https://warburg.library.cornell. edu/, https://warburg.library.cornell.edu/panel/b

Conf. The Mnemosyne Atlas, October 1929, The Warburg Institute, School of Advanced Study University of London, https://warburg.sas.ac.uk/collections/warburg-institute-archive/bilderatlas-mnemosyne/mnemosyneatlas-october-1929.

Conf. GREGORI, Daniela: Aby Warburg's Mnemosyne Atlas, Goethe Institut, 2016, translation Jonathan Uhlaner, https://www.goethe.de/en/kul/bku/20867100.html.

45 WARBURG: The Absorption of the Expressive Values of the Past, 276-277.

46 WARBURG, 276-277.

47 CONNERTON, Paul: How Societies Remember, Cambridge University Press, Cambridge 2013, Kindle edition, Loc. 114. 
work of compilation to recollect reports from the colonial age), H. Bancroft (recording testimonies of California pioneers in the 1860s), as well as Allan Nevins who attempted to reconstruct U.S. history since the late 19th century in 1948 through oral reports. ${ }^{48}$ Eviatar Zerubavel relied on a concept of sociomental topography of past events (rooted in sociology of memory, built upon those recollections that are shared by entire groups), belonging to social areas of memory and opening paths to discover the history remembered by communities. ${ }^{49}$ Zerubavel explained that group's memories are a part of a process of absorbing social identity (through collective past) and than a mean to assimilate new members of the community (through the knowledge of the common past of the group). ${ }^{50}$ Eric Hobsbawm show a linkage between public (or social) memory and social activism in surprising patterns of remembrance referring to Italian southern brigands of 19th century as people's heroes and champions of national liberation ("social bandits").51 Jill Edy (following Hobsbawm and Ranger study giving a picture of relative independence of social visions of the past from its historical substance) persuaded that (1) collective memory fall under the power of bureaucracy, and (2) there is no single social actor able to control how the loose narrative on the past is being developed..$^{52}$ As an example of social attempts to build common framework of using past for publicly important goals (or national) Edy mentioned Palestinian Jews pre WWII efforts to revoke memory of Masada, following Schwartz, Zerubavel and Barnett study on Masada defense recollection in 1920s Palestinian Jews narrative as a conscious effort to find equivalence between the severe fate of the last defenders of ancient Israel destroyed by Roman armies and contemporary (1920s) marginalized Jewish inhabitants of their ancient homeland in Palestine. ${ }^{53}$ Schwartz, Zerubavel and Barnett explained that the long-forgotten story of the defenders of Masada, who were still fighting against emperor Titus' son general Silva army in AD 73 (2 years of the sack

48 those data banks were lead by a different method than those used by sociologists Florian Znaniecki and W.I. Thomas after WWI to study biographical reports of immigrants. WACHTEL, Nathan: Introduction, in: Between Memory and History, ed. BOURGUET, Marie-Noelle - VALENSI, Lucette - WACHTEL, Nathan, transl. Sharon Romeo, Routledge, London 1990, Kindle Loc. 69-80.

49 ZERUBAVEL, Eviatar: Time Maps. Collective Memory and the Social Shape of the Past, The University of Chicago Press, Chicago 2004, Kindle, Loc. 153.

50 e.g. teaching immigrants to the U.S. on Mayflower pilgrims-settlers. ZERUBAVEL, Loc. 166.

51 HOBSBAWM, Eric: Primitive Rebels: Studies in Archaic Forms of Social Movement in the 19th 20th Centuries, Manchester University Press, Manchester 1959, 21.

Conf. on cognitive perspective of social outskirts of memory see WYER, Robert S. - SRULL, Thomas: Memory and Cognition in Its Social Context, Lawrence Erlbaum Associates, Hillsdale 1989, p. 19.

52 EDY, Jill A.: Troubled Pasts: News and the Collective Memory of Social Unrest, Temple University Press, Philadelphia 2006, 14-15.

53 Ibidem. 
and destruction of Jerusalem by Romans) in a remote mountain fortress, to commit suicide in order to reject Romans the fruits of victory, was revoked by Yitzhak Lamdan poem of 1927 and soon after, archeological evidence on the validity of the defense as historical fact. ${ }^{54}$ Ben Gurion's historical policy, as Y. Zerubavel explained, in 1943 was comparing Masada defense to the 1920 defense of Tel Hai settlement ("«a second Masada»") calling Jewish settlers in Palestine to perform an armed self-defense, to use weapons and to die carrying a gun (importantly due to general lack of resistance, with such exceptions as Warsaw Ghetto Uprising, of Holocaust victim, as Y. Zerubavel noted, their cause and history was not largely popular or consciously revoked in Israel since 1940s until early 1960s due to the spirit of armed fight for Israel and expectations of heroic, warrior-like behaviour on the Jewish side). ${ }^{55}$ Y. Zerubavel explained that Tel Hai (settlement) defense of 1 March 1920 against Arab invaders were compared to Masada though the number of defenders were small, but one of key Jewish military heroes of the time, Yosef Trumpeldor died just after that shoot-out, wounded, and for the small 1920 Yishuv in Palestine (57 thousand of Jews) the loss of that settlement and other in Upper Gallilee (due to weak French control and Arab uprising), taking into account 8 dead settlers in that battle was a huge loss. ${ }^{56}$

The Holocaust experience' centrality in modern Israel could be understood within a framework of "postmemory" used by Zerubavel after Marianne Hirsch as method of analysing the impact of traumatic recollections of the WWII Nazi crimes against Jews by the survivors, whose memory (as more important, more powerful) was displacing own images of the past held by the second generation, the children of Holocaust survivors. ${ }^{57}$

54 Josephus Flavius The Jewish War was not fully confirmed until modern archeology. SCHWARTZ, Barry ZERUBAVEL, Yael - BARNETT, Bernice, The Recovery of Masada: A Study in Collective Memory, The Sociological Quarterly, 27, 1986, 2, 148.

Masada itself, as for 2007 was a highly popular place among tourist trips to Israel, the old Herod's fortress was partly restored, with some parts of pre-Roman pacification chambers of the Idumean king presented, while the fortress could be serving in 2000s more like a symbol of Israeli military power, than a place of suffering and defeat (in the visitors eye). Masada was identified under Byzantine age in 1838, Israeli research began in 1953, Masada National Park, https://www.parks.org.il/en/reserve-park/masada-national-park/.

The fortress Masada (following J. Flavius) was built 37-31 BC by Herod. Archelogy in Israel: Masada Desert Fortress, Jewish Virtual Library, https://www.jewishvirtuallibrary.org/masada-desert-fortress

Masada, UNESCO, https://whc.unesco.org/en/list/1040/

Josephus Flavius, The Wars of the Jews, ed. WHISTON, William, A.M. Auburn and Buffalo, John E. Beardsley 1985, www.perseus.tufts.edu/hopper/text?doc=Perseus\%3Atext\%3A1999.01.0148.

55 ZERUBAVEL, Yael: The Death of Memory and the Memory of Death: Masada and the Holocaust as Historical Metaphors, Representations, 45, 1994, 79-80.

56 ZERUBAVEL, Yael: Recovered Roots. Collective Memory and the Making of Israeli National Tradition, The University of Chicago Press, Chicago and London 1995, p. 39-41.

57 ZERUBAVEL, Yael: The "Mythological Sabra" and Jewish Past: Trauma, Memory, and Contested Identities, in: Israel Studies, 7, 2002, 2, 132. Among the vehicles of postmemory that link recollections of Holocaust survivors with their past and the ghetto one particularly interesting object was a inch-high book (a gift of patients to dr. Arthur Kessler in the camp Vapniarka he left to go to Olgopol ghetto, with drawings depicting camp life and images of liberation, whose son David inherited it). HIRSCH, Marianne - SPITZER, Leo: Ghosts of Home: The Afterlife of Czernowitz in Jewish Memory, University of California Press, Berkeley 2010, 219-221. Such artifacts could pose a powerful obstacle to threat of " "social forgetting" following Van Vree view, that encompasses painful or shameful events and could touch either genocide remembrance or such crimes as child abuse. HIRSCH, Marianne: Reframing "Absent Memories", in: Cultural Analysis, 12, 2013, 16-17. 
To analyze the impact of politics of memory on PRC post-Cold War foreign policy Zheng Wang introduced new research pattern, relying on assessments of historical memory's role in selected social employments (identity contents):

- creating rules of group membership,

- building comparisons to other groups,

- becoming one of cognitive factors of understanding the world by group members,

- supplying the selection of roles performed by the group (seen as proper). ${ }^{58}$

Additionally Zheng Wang built a causal framework of analysis of historical memory beliefs as factors of political actions, including the role of such beliefs (or ideas) as:

- blueprints allowing political actors to define their goals,

- litmus paper ("focal points") that leads either to increased group cohesion (relying on historical beliefs) or heightened conflict,

- basis of a process of institutionalization of historical beliefs to create socially binding constraints. ${ }^{59}$

Among memory studies methods Erica Johnson distinguished affective archive as new turn in historical concepts, owing much to feminist theory, focused on the role of emotions and sensations and seeing such personal traits to archives an innovative path to reach a new perspective of the past, the less objectivist but enriched by earlier marginalized individual perspectives (feelings). ${ }^{60}$

\section{The case of $9 / 11$ and collective memory}

Simko noted with a stress on American culture and collective memory, that it sounded strange to those who remember Hiroshima that September 11th attacks' aftermath was labelled "«ground zero»" same as the devastation after dropping atomic bombs against Japanese cities (following US Strategic bombing Survey), when the U.S. was causing the destruction (so after 9/11) the label referred to a place of American victimhood, the meaning in collective comprehension became reversed in terms of moral outrage and relation between the destroyer and the destroyed..$^{61}$ Ground zero first referred to a foot of a tower when the pioneer Trinity test of a nuclear device was performed (July 1945). ${ }^{62}$

58 WANG, Zheng: Never Forget National Humiliation. Historical Memory in Chinese Politics and Foreign Relations, Columbia University Press, New York 2012, Kindle edition, Loc. 470-484.

59 WANG, Loc. 470-484.

60 JOHNSON, Erica: Cultural Memory, Memorials, and Reparative Writing, Palgrave Pivot, Cham 2018, 7-9.

61 SIMKO, Christina: Forgetting to Remember: The Present Neglect and Future Prospects of Collective Memory in Sociological Theory, in: Handbook of Contemporary Sociological Theory, ed. ABRUTYN, Seth, Springer ebook, 470-471, DOI 10.1007/978-3-319-32250-6_22.

The terms " "ground zero»" and "«air zero»" were used in the report of U.S. Strategic Bombing Survey: The Effects of the Atomic Bombings of Hiroshima and Nagasaki, June 19, 1946. Truman Papers, 5, https://www.trumanlibrary. org/whistlestop/study_collections/bomb/large/documents/pdfs/65.pdf.

62 National Park Service, https://www.nps.gov/whsa/learn/historyculture/trinity-site.htm

US Department of Energy, https://www.energy.gov/lm/programs-and-services/stakeholder-engagement/ manhattan-project-national-historical-park, https://www.energy.gov/management/trinity-site-worlds-first-nuclearexplosion

Conf. GOSLING, F. G.: Manhattan Project, 2010, https://www.osti.gov/opennet/manhattan-project-history/ publications/Manhattan_Project_2010.pdf. 
Then ground zero label was applied to detonation centers in Hiroshima and Nagasaki (August 1945)..$^{63}$ Soon after 9/11 attacks in the course of the investigation for NYC label ground zero was used to describe the holes in earth after WTC towers demolished by AlQaeda hijacked civilian airplanes. ${ }^{64}$ Oz Frankel judged 9/11 commission report, Kean, Hamilton, Zelikow was an attempt to attract the attention of broader public by aggressive marketing and a way of surfing between state building traditions of the progressive era and neoliberal mind to establish the commissions effort in terms of collective memory after Pierre Nora. ${ }^{65}$

Lee Hamilton and others report mentioned Pearl Harbour and Kennedy assassination among top historical comparisons to $9 / 11$ stressing none is adequate. ${ }^{66}$ 9/11 commission report summary stated that the remembrance on the attack would include national unification due to the tragedy and its fruits as expected non partisan cooperation on matters of international terrorism. ${ }^{67}$

\section{Conclusion}

The key concepts of memory studies, such as collective memory, social memory and cultural memory could be in support of each other while showing different research and public perspectives on the past. Those methodological traits (or approaches) may also counteract, or lead to different common understanding of what was and is important in the recent past (as in post-communist world). Such discrepancies may be of political significance in countries in transition. On the other hand, the variety of approaches to definitions and developments in the area of memory studies could inspire more interdisciplinary efforts in the field, leading to new historical thesis that invigorate present-day social or national goals, as in Israel, seeking more solid grounds to its difficult reconstruction, symbolic and material in the 20th century. Another problem regarding memory studies is revealed by social rituals and generational change in the matter of remembering difficult

63 DOWER, John W.: Ground Zero 1945. Pictures by Atomic Bomb Survivors, 2008, https://visualizingcultures. mit.edu/groundzero1945/gz_essay01.html.

64 USGS Environmental Studies of the World Trade Center Area, New York City, after September 11, 2001, https://pubs.usgs.gov/fs/fs-0050-02/fs-050-02_508.pdf

A travelling exhibition After 9/11: Messages from the World and images of ground zero, https://2001-2009.state. $\mathrm{gov} / \mathrm{r} / \mathrm{pa} / \mathrm{prs} / \mathrm{ps} / 2002 / 13358 . \mathrm{htm}$

TRUMP, Donald: Remarks by President Trump at September 11th Pentagon Observance Ceremony, September 11, 2019, https://www.whitehouse.gov/briefings-statements/remarks-president-trump-september-11th-pentagonobservance-ceremony/.

65 FRANKEL, Oz: The 9/11 Commission Report: History Under the Sign of Memory, in: The Palgrave Handbook of State-Sponsored History After 1945, eds. BEVERNAGE, Berber - WOUTERS, Nico, Palgrave Macmillan, London 2018, 666-667.

66 HAMILTON, Lee et altera: 9/11 Commission Report, 2004, http://govinfo.library.unt.edu/911/ report/911Report_Statement.pdf, https://www.9-11commission.gov/report/.

67 9/11 commission executive summary, 26, http://govinfo.library.unt.edu/911/report/911Report_Exec.pdf, Among the key controversial issue was linkage between Osama bin Laden and Saddam Hussein Iraq, the report mentioned ClA establishment on the training of Iraq government bomb making specialist in Osama bin Laden training camp near Khartoum in 1995 and 1996 which were also disputed. 9/11 commission report, 468, notes to chapter 2, http://govinfo.library.unt.edu/911/report/911Report.pdf. 
or degrading deeds, like German-committed Holocaust: is it going to be well discussed from the perspective of perpetrators? A question arise whether main traits in memory studies seem to contribute more to research progress in the field or to the social understanding of the past - or is it the correct, genuine emotional approach to past achievements and wrongdoings in society as a whole?

\section{References}

A travelling exhibition After 9/11: Messages from the World and images of ground zero, Available from: https://2001-2009.state.gov/r/pa/prs/ps/2002/13358.htm.

9/11 commission executive summary, Available from: http://govinfo.library.unt.edu/911/ report/911Report_Exec.pdf, Among.

Archelogy in Israel: Masada Desert Fortress, Jewish Virtual Library, Available from: https:// www.jewishvirtuallibrary.org/masada-desert-fortress.

BBC News, India wife dies on husband's pyre, August 22, 2006, news.bbc.co.uk/2/hi/ south_asia/5273336.stm.

Masada National Park, Available from: https://www.parks.org.il/en/reserve-park/masadanational-park/.

Masada, UNESCO, Available from: https://whc.unesco.org/en/list/1040/.

Mnemosyne. Meanderings through Aby Warburg's Atlas, Cornell University Library, Available from: https://warburg.library.cornell.edu/, https://warburg.library.cornell.edu/ panel/b.

National Park Service, Available from: https://www.nps.gov/whsa/learn/historyculture/ trinity-site.htm.

The Mnemosyne Atlas, October 1929, The Warburg Institute, School of Advanced Study University of London, Available from: https://warburg.sas.ac.uk/collections/warburginstitute-archive/bilderatlas-mnemosyne/mnemosyne-atlas-october-1929.

US Department of Energy, Available from: https://www.energy.gov/lm/programs-andservices/stakeholder-engagement/manhattan-project-national-historical-park, Available from: https://www.energy.gov/management/trinity-site-worlds-first-nuclear-explosion.

USGS Environmental Studies of the World Trade Center Area, New York City, after September 11, 2001, Available from: https://pubs.usgs.gov/fs/fs-0050-02/fs-050-02_508. pdf. 
U.S. Strategic Bombing Survey: The Effects of the Atomic Bombings of Hiroshima and Nagasaki, June 19, 1946. Truman Papers, Available from: https://www.trumanlibrary. org/whistlestop/study_collections/bomb/large/documents/pdfs/65.pdf.

APFELBAUM, Erika: Halbwachs and the Social Properties of Memory, in: Memory: Histories, Theories, Debates, ed. RADSTONE, Susannah - SCHWARZ, Bill, Fordham University Press, New York 2010, 77-92.

ASSMANN, Jan: Cultural Memory. Writing, Remembrance, and Political Imagination in Early Civilization, translated by Henry David Wilson, Cambridge University Press, Cambridge 2011.

BRANTE, Thomas: Consequences of Realism for Sociological Theory Building, in: Journal for the Theory of Social Behaviour, 31, 2001, 2, 167-195.

CONNERTON, Paul: How Societies Remember, Cambridge University Press, Cambridge 2013.

CORNIG, Amy - SCHUMAN, Howard: Generations and Collective Memory, The University of Chicago Press, Chicago 2015.

CUBITT, Geoffrey: History and Memory, Manchester University Press, Manchester 2007.

DHILLON, Maninder: Widow Burning: The Burning Issue of Colonial Britain and India, Blog, Utrecht University, 2019. Available from: https://cchr.uu.nl/widow-burning-the-burningissue-of-colonial-britain-and-india/.

DOWER, John W.: Ground Zero 1945. Pictures by Atomic Bomb Survivors, 2008. Available from: https://visualizingcultures.mit.edu/groundzero1945/gz_essay01.html.

DURKHEIM, Emile: The Elementary Forms of the Religious Life, translated by Joseph Ward Swain, Free Press, New York 1965.

EDY, Jill A.: Troubled Pasts: News and the Collective Memory of Social Unrest, Temple University Press, Philadelphia 2006.

ERLL, Astrid, Cultural Memory, in: English and American Studies, eds. MIDDEKE, Martin et altera, J. B. Metzler, Stuttgart 2012, 238-242.

ERLL, Astrid: Regional integration and (trans)cultural memory, in: Asia Europe Journal, 2010, 8, 305-315. 
FRANKEL, Oz: The 9/11 Commission Report: History Under the Sign of Memory, in: The Palgrave Handbook of State-Sponsored History After 1945, eds. BEVERNAGE, Berber - WOUTERS, Nico, Palgrave Macmillan, London 2018, 653-668.

GEDI Noa - ELAM, Yigal: Collective Memory - What Is It?, in: History and Memory, 8, 1996, $1,30-50$.

GOSLING, Francis G.: Manhattan Project, 2010. Available from: https://www.osti.gov/ opennet/manhattan-project-history/publications/Manhattan_Project_2010.pdf.

GREGORI, Daniela: Aby Warburg's Mnemosyne Atlas, Goethe Institut, 2016, translation Jonathan Uhlaner. Available from: https://www.goethe.de/en/kul/bku/20867100.html.

HALBWACHS, Maurice: Individual and Collective Psychology, in: American Sociological Review, 3, 1938, 5, 615-623.

HALBWACHS, Maurice: La mémoire collective et le temps, in: Cahiers internationaux de sociologie, 101, 1996 (1947), 45-65.

HALBWACHS, Maurice: The Psychology of Social Class, translated by Claire Delavaney, William Heinemann, London 1958.

HAMILTON, Lee et altera: 9/11 Commission Report, 2004. Available from: http://govinfo. library.unt.edu/911/report/911Report_Statement.pdf, https://www.9-11commission.gov/ report/.

HARDING, Luke: The ultimate sacrifice, The Guardian, August 23, 2002. Available from: https://www.theguardian.com/world/2002/aug/23/gender.uk1.

HERVIEU-LÉGER, Danièle: Religion as a Chain of Memory, translated by Simon Lee, Rutgers University Press, New Brunswick 2000.

HERVIEU-LÉGER, Danièle: Space and Religion: New Approaches to Religious Spatiality in Modernity, in: International Journal of Urban and Regional Research, 26, 2002, 1, 99-105.

HIRSCH, Marianne - SPITZER, Leo: Ghosts of Home: The Afterlife of Czernowitz in Jewish Memory, University of California Press, Berkeley 2010.

HIRSCH, Marianne: Reframing "Absent Memories", in: Cultural Analysis, 12, 2013, 16-17.

HIRSCH, Thomas: A Posthumous Life. Maurice Halbwachs and French Sociology (19452015), translated by Peter Hamilton, in: Revue française de sociologie, 57, 2016, 1, 48-71. 
HOBSBAWM, Eric: Primitive Rebels: Studies in Archaic Forms of Social Movement in the 19th 20th Centuries, Manchester University Press, Manchester 1959.

IBLER, Roland: Cultural memory, in: The Bonn Handbook of Globality, eds. KÜHNHARDT, Ludger - MAYER, Tilman, Vol. 2, Springer, Cham 2019, 807-819.

JOHNSON, Christopher D., About the Mnemosyne Atlas, The Warburg Institute, Cornell University Library, 2013-2016. Available from: https://warburg.library.cornell.edu/about.

JOHNSON, Erica: Cultural Memory, Memorials, and Reparative Writing, Palgrave Pivot, Cham 2018.

JOSEPHUS (Flavius): The Wars of the Jews, ed. WHISTON, William, A.M. Auburn and Buffalo, John E. Beardsley 1985. Available from: www.perseus.tufts.edu/hopper/ text?doc=Perseus\%3Atext\%3A1999.01.0148.

KELLAND, Lara Leigh: Clio's Foot Soldiers. Twentieth-Century U.S. Social Movements and Collective Memory, University of Massachusetts Press, Amherst and Boston 2018.

KOSELLECK, Reinhart: Social History and Conceptual History, in: International Journal of Politics, Culture, and Society, 2, 1989, 3, 308-325.

LANGENBACHER, Eric: Collective Memory as a Factor in Political Culture and International Relations, in: Power and the Past. Collective Memory and International Relations, eds. LANGENBACHER, Eric - SHAN, Yossi, Georgetown University Press, Washington D.C. 2010, Kindle, Loc. 184-711.

LENSEN, Jan: Towards a Transnational Ethics for Europe: Memory and Vulnerability as Gateways to Europe's Future in Koen Peeters's Grote Europese roman, in: The Changing Place of Europe in Global Memory Cultures. Usable Pasts and Futures, eds. KRAENZLE, Christina - MAYR, Maria, Palgrave Macmillan, Cham 2017, 87-101.

LEWIS, Bernard: History. Remembered, Recovered, Invented, Princeton University Press, Princeton 1975.

LLOBERA, Joseph: Halbwachs, Nora and "history" versus "collective memory": a research note, Durkheimian Studies, 1, 1995, 35-44.

MACNEILL, Dominique: Extending the work of Halbwachs: Danièle Hervieu-Léger's analysis of contemporary religion, Durkheimian Studies, 4, 1998, 73-86. 
MUNK, Jan: Activities of Terezín Memorial, in: The Public Historian, 30, 2008, 1, 73-79. Terezín Children of the Holocaust, http://www.terezin.org/the-history-of-terezin. Terezín Memorial National Cultural Monument. Available from: https://www.pamatnik-terezin.cz/ small-fortress.

NALBORCZYK, Agata: Community Life: Cultural Memory and the Construction of a Contemporary Muslim Tatar Identity in Poland, in: Contested Memories and the Demands of the Past. History Cultures in the Modern Muslim World, ed. RAUDVERE, Catharina, Palgrave Macmillan, Cham 2017, 149-177.

NORA, Pierre: Between Memory and History: Les Lieux de Mémoire, translated by Marc Roudebush, in: Representations, 26, 1989, 7-24.

OLICK, Jeffrey: The Politics of Regret. On Collective Memory and Historical Responsibility, Routledge, New York 2007.

PESTA, Jesse - RANA, Preetika: In Indian Families, the Dangerous Meeting of Women and Fire, The Wall Street Journal, July 22, 2015. Available from: https://www.wsj.com/ articles/in-indian-families-the-dangerous-meeting-of-women-and-fire-1437606446.

RICOEUR, Paul: Memory, History, Forgetting, translated by Kathleen Blamey and David Pellauer, The University of Chicago Press, Chicago 2006.

ROTTLEUTHNER, Hubert: Foundations of Law, in: A Treatise of Legal Philosophy and General Jurisprudence, Vol. 2, eds. PATTARO, Enrico, Springer, Dordrecht 2005, 7.

RUSSELL, Nicolas: Collective Memory before and after Halbwachs, in: The French Review, 79, 2006, 4, 792-804.

SAARISTO, Antti Jussi: Social Ontology and Agency. Methodological Holism Naturalised, Presented to the University of London for the degree of Doctor of Philosophy, March 2007. Available from: http://etheses.Ise.ac.uk/2561/1/U615510.pdf.

SCHWARTZ, Barry - ZERUBAVEL, Yael - BARNETT, Bernice, The Recovery of Masada: A Study in Collective Memory, The Sociological Quarterly, 27, 1986, 2, 147-164.

SIMKO, Christina: Forgetting to Remember: The Present Neglect and Future Prospects of Collective Memory in Sociological Theory, in: Handbook of Contemporary Sociological Theory, ed. ABRUTYN, Seth, Springer ebook, 457-475.

SINGH, Bhajan: Institution of Sati in Medieval India with Special Reference to Pre-Colonial Punjab, Proceedings of the Indian History Congress, 71, 2010-2011, 256-265. 
STEIN, Dorothy K.: Women to Burn: Suttee as a Normative Institution, Signs, 4, 1978, 2, 253-268.

TILEAGĂ, Cristian: Representing Communism After the Fall. Discourse, Memory, and Historical Redress, Palgrave Macmillan, Cham 2018.

TROEBST, Stefan: Surfacing of the "Titanic" in the Balkan Bermuda Triangle: Historicalpolitical Conflicts between Sofia, Skopje and Athens before and after 1989, in: History as an Instrument of Contemporary International Conflicts, eds.

RYDEL, Jan - TROEBST Stefan, International Conference, Cracow, October 2018, 25-27.

TRUMP, Donald: Remarks by President Trump at September 11th Pentagon Observance Ceremony, September 11, 2019. Available from: https://www.whitehouse.gov/briefingsstatements/remarks-president-trump-september-11th-pentagon-observance-ceremony/.

TUMBLETY, Joan: Introduction. Working with memory as source and subject, in: Memory and History. Understanding memory as source and subject, ed. TUMBLETY, Joan, Routledge, London 2013.

VERVAET, Stijn: Writing war, writing memory. The representation of the recent past and the construction of cultural memory in contemporary Bosnian prose, in: Neohelicon, 38, 2011, 1-17.

WACHTEL, Nathan: Introduction, in: Between Memory and History, ed. BOURGUET, MarieNoelle - VALENSI, Lucette - WACHTEL, Nathan, transl. Sharon Romeo, Routledge, London 1990.

WAHLBERG, Tobias Hansson: Elder-Vass on the Causal Power of Social Structures, in: Philosophy of the Social Sciences, Sage, Online August 29, 2013. Available from: https:// lucris.lub.lu.se/ws/files/1304165/4612198.pdf.

WANG, Zheng: Never Forget National Humiliation. Historical Memory in Chinese Politics and Foreign Relations, Columbia University Press, New York 2012.

WARBURG, Aby: The Absorption of the Expressive Values of the Past, translated by Mathew Rampley, in: Art in Translation, 1, 2009, 2, 273-283.

WEBER, Max: The Protestant Ethics and the Spirit of Capitalism, translated by Talcott Parsons, Charles Scribner's Sons, New York 1958.

WYER, Robert S. - SRULL, Thomas: Memory and Cognition in Its Social Context, Lawrence Erlbaum Associates, Hillsdale 1989. 
ZERUBAVEL, Eviatar: Time Maps. Collective Memory and the Social Shape of the Past, The University of Chicago Press, Chicago 2004.

ZERUBAVEL, Yael: Recovered Roots. Collective Memory and the Making of Israeli National Tradition, The University of Chicago Press, Chicago 1995.

ZERUBAVEL, Yael: The "Mythological Sabra" and Jewish Past: Trauma, Memory, and Contested Identities, in: Israel Studies, 7, 2002, 2, 115-144.

ZERUBAVEL, Yael: The Death of Memory and the Memory of Death: Masada and the Holocaust as Historical Metaphors, Representations, 45, 1994, 7-100.

\section{Author}

dr hab. Grzegorz Nycz, Ph.D. university professor

Pedagogical University of Cracow

Podchorążych 2, 31-084 Kraków, Poland

grzegorz.nycz@up.krakow.pl 